\title{
International Journal of Supply Chain Management (IJSCM)
}

EFFECTS OF ECOLOGICAL DESIGN SYSTEMS ON SUSTAINABLE ENVIRONMENTAL CONSERVATION OF TEA FACTORIES IN NANDI COUNTY

Clinton Kioko Maluki and Dr. Pauline Keitany

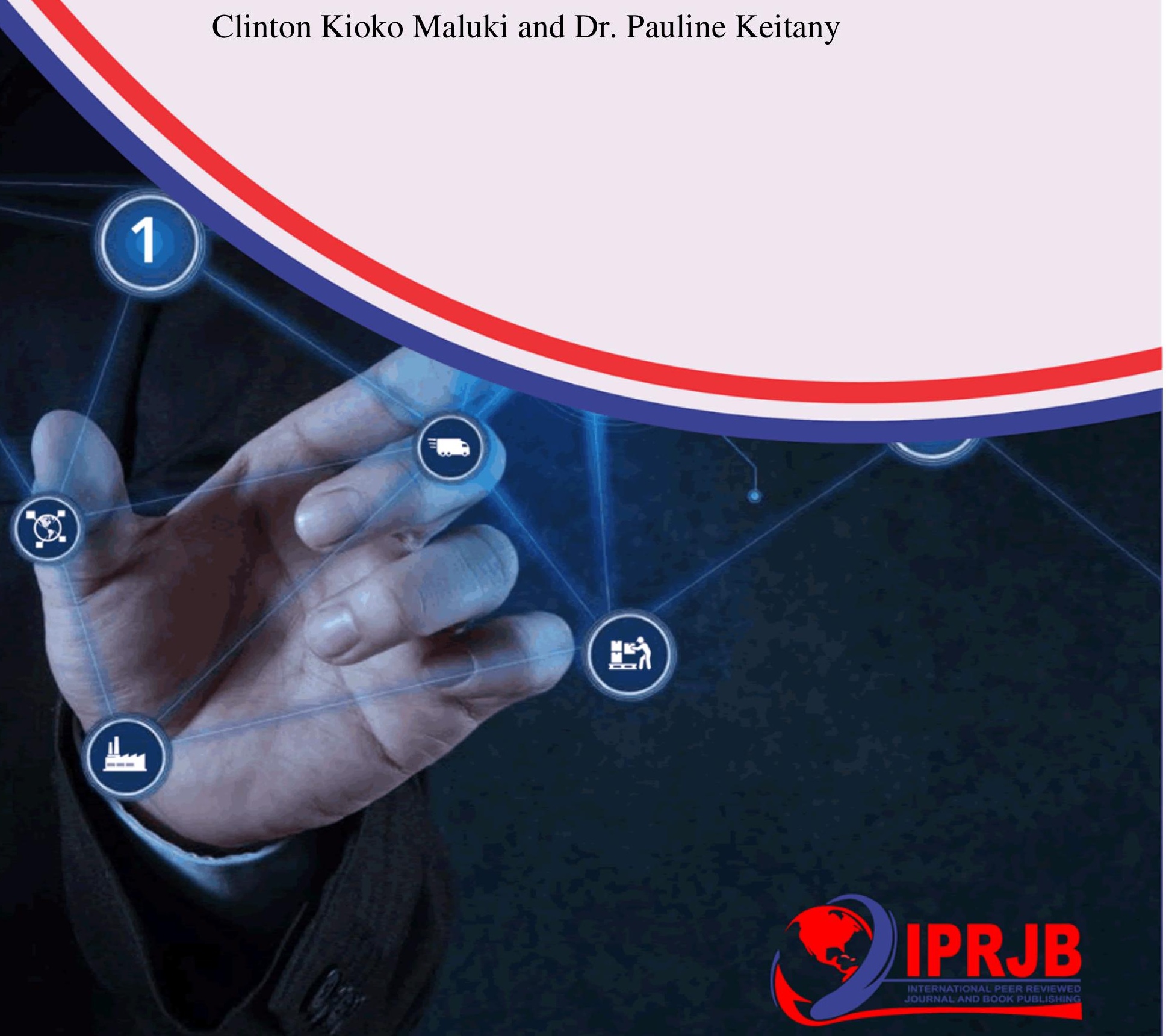


International Journal of Supply Chain Management

ISSN 2518-4709 (Online)

Vol.6, Issue 2, No.1, pp 1-11, 2021

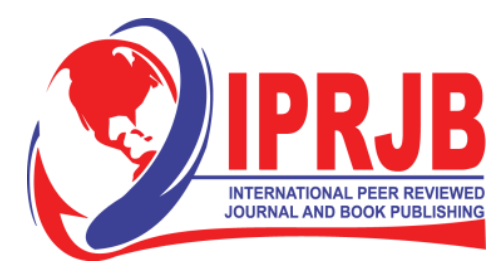

Www.iprib.org

\title{
EFFECTS OF ECOLOGICAL DESIGN SYSTEMS ON SUSTAINABLE ENVIRONMENTAL CONSERVATION OF TEA FACTORIES IN NANDI COUNTY
}

\author{
${ }^{1 *}$ Clinton Kioko Maluki \\ Post Graduate Student: Jomo Kenyatta University of Agriculture and Technology \\ Email:clintonkioko67@gmail.com \\ ${ }^{2}$ Dr. Pauline Keitany \\ Lecturer: Department of Procurement and Logistics, University of Kabianga \\ Email:polynkeitany@gmail.com
}

\begin{abstract}
Purpose: The main purpose of this study was to examine the effects of ecological design systems on sustainable environmental conservation of tea factories in Nandi County. The study was guided by transaction economic cost theory.

Methodology: The study used explanatory research design to help in exploring research questions with varying levels of depth. A semi-structured questionnaire with Likert-type interval scale anchored on a five-point scale was used to collect primary data. A pilot study was conducted in Eldoret Kiptagich tea wholesalers to test the validity of research instrument, Cronbach's alpha formular was used to test reliability. The analysis technique included both descriptive statistics (means, standard deviation, percentages \& frequencies) and inferential which included multiple regression analysis conducted at $95 \%$ confidence level with significance levels of 0.05 . Data has been presented in tabular format.
\end{abstract}

Findings: The findings of the study indicated that ecological design practices had positive and significant influence on sustainable environmental conservation of tea factories in Nandi county $(\beta=0.113 ; \mathrm{p}<0.05)$. The study concluded that ecological design, reverse logistics, green production and green procurement are the predictors of sustainable environmental conservation of tea factories in Nandi county. The study recommends that more participation of national government on implementation of sustainable environmental conservation is necessary to ensure that the future generation is well taken care of by ensuring the four-bottom line of sustainable supply chain are practiced. The study also recommends tea processing firms and other manufacturing firms adopt GSCM practices in their supply chain operations. The study suggests that further studies should be conducted in processing firms other than tea processing firms.

Unique contribution to theory, practice and policy: Further studies can be conducted to relate GSCM with individual aspects of performance such as Economic, Environmental and Social and future other replica studies can be done on the areas of ecological design on sustainable performance.

Key words: Ecological Design, Systems, Environmental Conservation, Sustainable and Environmental Conservation. 
International Journal of Supply Chain Management

ISSN 2518-4709 (Online)

Vol.6, Issue 2, No.1, pp 1-11, 2021

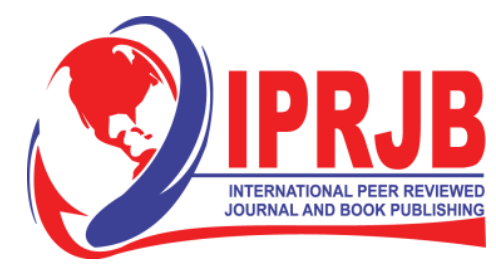

WWW.iprib.org

\subsection{INTRODUCTION}

Sustainable environmental conservation in tea farming is an approach to farming systems that aims at improving the environment and well-being of communities now and in the future while recognizing that farm profitability needs to be maintained or possibly improved (Aital \& Vijai, 2016). Green Supply Chain Management is the practice of monitoring and improving environmental performance in the supply chain by integrating environmental thinking into supply chain management throughout a product's life cycle (Srivastava, Green supply-chain management: a state-of-the-art literature review, 2007). Ngugi\& Nderitu (2014) argue that the waste and emissions caused by the supply chain have become the main sources of serious environmental problems, including global warming and acid rain. Organizations have several reasons, such as -reactive regulatory reasons, proactive strategic and competitive advantage reasons- for implementing green supply chain policies (Nderitu \& Ngugi, 2014). From an overall environmental and organizational perspective, it is vital to understand the situation and what issues exist in this field of study.

This synergy is expected to enhance the corporate image, competitive advantage, and marketing exposure. From the global perspective, with the globalization of economies, supply chain management has become a promising area in achieving sustainability due to international environmental pressures and the concept of "green supply chain management (GSCM)" (Nderitu $\&$ Ngugi, 2014). The concept of supply chain environmental management has been observed as a recent and innovative managerial principle. This topic's originality makes it difficult to truly determine contradictory and conflicting issues that could be considered valid "debates." Sarkis et al. (2005) provide a comprehensive view of the state of research in this evolving topic, tracing researchers investigating the issues involving, the reasons for incorporating these practices, and how they have been practiced in various organizations.

Today's business environment is characterized by increasing uncertainties. GSCM has emerged as a critical new approach for enterprises to achieve profit and market share objectives by reducing environmental risk and impact (Muma, Nyaoga, Matwere, \& Nyambega, 2014). In the U.S.A., for example, Nike has a well-established sustainability system. As the largest producer of athletic footwear globally, Nike has a significant impact on people and resources worldwide (Lampikoski, Westerlund, Rajala, \& Moller, 2014). The company has recognized its dependence on fossil fuel energy and oil for materials, exposing them to high oil prices or carbon restrictions in the future. Meanwhile, waste production and use of toxic materials and water also pose major risks. Nike has created a strategic alliance with an eco-non-profit organization, "National Recycling Coalition" (N.R.C.), to collect used tennis shoes as part of Nike's Reuse a Shoe Program (Kumar \& Malegeant, 2006).

This shows they have a well-established reverse logistic system. Further, they have a policy on factory emissions to minimize global warming by burning most of their wastes in an incinerator (Kumar \& Malegeant, 2006). The Nike name, generally linked to success and wealth, first got into trouble in the early '90s when footage of sweatshops and child labor in their factories was broadcast on international television, thus tainting their name worldwide (Bullert, 2000). This made them advance their policy on wages and legal age to work in their factories. This has shown how sustainable procurement can positively impact performance. However, Nike could 
International Journal of Supply Chain Management

ISSN 2518-4709 (Online)

Vol.6, Issue 2, No.1, pp 1-11, 2021

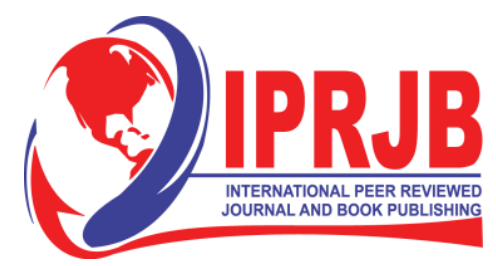

WWW.iprib.org

not diverge most of the information on how much performance was enhanced on this due to high competition (Bullert, 2000).

\section{Statement of the problem}

Green supply chain management is rooted in the principle of pollution prevention, which strives to eliminate or to reduce risks to human health and the environment. To enhance environmental conservation, tea processing firms have adopted green initiatives such as afforestation and reafforestation, use of efficient energy sources and improved waste management. Despite these initiatives, there is continued outcry by the tea factories managed by the Kenya Tea Development Authority on behalf of small-scale farmers where the cost of production has continued to rise due to high energy, labor, and leveraging on economies of scale to negotiate cheaper input purchases for smallholder farmers besides an ever-increasing degradation of soil in tea producing areas. (Mukiri, 2007). Some of the challenges highlighted by tea factories in Nandi county include high cost of production, soil degradation, poor governance among cooperatives, tea hawking where brokers continue to use information asymmetry to farmers disadvantage, poor local market conditions, delayed payments to farmers, poor distribution channels, among others (County Government of Nandi, 2020). The majority of the factories are on their downfall trend; farmers are continually losing hope and shifting to maize farming, which has numerous challenges. Undeniably, reducing air, water and waste pollution is the main goal of green supply chain management. This research was carried out in Nandi County, one of the large-scale tea growing area mainly in plantations. It is clear that there is a need for further exploration in this area; this study aims to bridge such gaps by exploring the effect of GSCM practices on sustainable environmental conservation of Tea Processing Factories in Nandi county. The study recommends solutions for adoption and implementation of suitable green supply chain management practices to curb the problem of high production costs. It also suggests policies to help address the problem of soil degradation, poor distribution channels, and poor governance among cooperatives. The study also recommends effective training programs for employees and employers within tea factories in Nandi county aimed at addressing skill gap.

\subsection{THEORETICAL REVIEW}

A theory is a supposition or a system of ideas intended to explain something, especially one based on general principles independent of the thing to be explained (Ghoshal \& Moran, 1996). This section therefore presents theoretical foundations that underlie the importance of green supply chain management practices on organization competitive performance.

\section{Transaction Cost Economic Theory}

This study utilized transaction cost theory; transaction cost economics is understood as alternative modes of organizing transactions (governance structures - such as markets, hybrids, firms, and bureaus) that minimize transaction costs (Williamson 1979). Transaction cost theory posits that the optimum organizational structure achieves economic efficiency by reducing the costs of exchange (Ghoshal \& Moran, 1996). The theory suggests that each transaction type produces coordination costs of monitoring, controlling, and managing transactions. Williamson has defined transaction costs broadly as the costs of running the economic system of firms. He has argued that such costs are distinguished from production costs and that a decision-maker can 
choose to use a firm structure or source from the market by comparing transaction costs with internal production costs. Thus, the cost is the primary determinant of such a decision. Transaction Cost Economic addresses these questions: Why do firms exist? What are the most effective strategies for maximizing profits? What should firms make? And what should firms buy?

The main theoretical argument of this theory is concerned with the conditions under which specific characteristics of the transaction or the object of the transaction would lead to its internal hybrid or external governance (Coase, 2009). It has two crucial fundamental behavioral assumptions bounded rationality (Nderitu \& Ngugi,2014). Bounded rationality refers to that people have rationality, but limited. Therefore, it is only possible for both parties in a transaction to sign incomplete contracts William, (2008) Opportunism refers to that people cunningly behave opportunistically at the expense of others. The sole existence of firms is to make a profit, and therefore, a firm that embraces a sustainable green supply chain management is better placed over its competitors. As global environmental problems mount, the transition to sustainable environmental conservation seems elusive (Carter \& Rogers, 2008). A major reason is that the world is facing a monumental challenge with the most formidable barriers being institutional barriers and transaction costs that replicate the same patterns of resource-based development, despite the rising costs associated with increasing environmental degradation (Carter \& Rogers, 2008). Reorienting economies to foster more sustainable environmental conservation will only succeed if tea factories overcome these institutional barriers and costs.

\section{Conceptual Framework}

The relationships of variables in this study have been conceptualized as shown in the Figure below. Green supply chain management activities are the independent variables of this study. In this respect; the aim is to find out how each of these variables (ecological design, reverse logistics, green production, and green procurement) influences sustainable environmental conservation of tea factories in Nandi county.

\begin{tabular}{|c|c|}
\hline Ecological Design & \\
\hline Ecological ventilation & $\begin{array}{c}\text { Sustainable } \\
\text { environmental } \\
\text { conservation }\end{array}$ \\
\hline Bio degradable packaging & 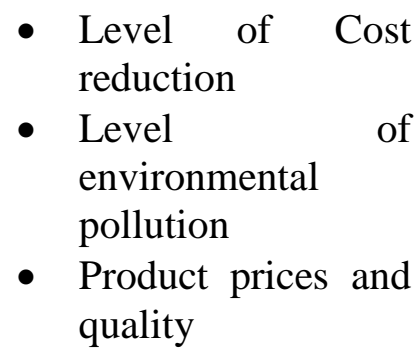 \\
\hline
\end{tabular}




\subsection{RESEARCH METHODOLOGY}

\section{Research Design}

Mugenda, (2013) defines research design as a plan and structure of investigating so as to obtain answers of a research question. This study adopted an explanatory research design. The explanatory approach allowed the research to understand the study variables through description or illustration. The name itself states that it intends merely to explore the research questions and does not offer final and conclusive solutions to existing problems (Adams, 2015). Exploratory research design does not aim at providing the final and conclusive answers to the posed research questions; rather it helps explore research topics with varying levels of depth. An explanatory approach helps in obtaining solutions to the existing problem which contributes to higher satisfaction for clients. Furthermore, explanatory approach helped the researcher in setting priorities, generating operational definitions and providing a better-researched model. Explanatory research design focuses on explaining the aspects of a study in a detailed manner and helps the researcher derive better conclusions (Adams, 2015).

\section{Target Population}

A population can be defined as a complete set of individuals, cases, or objects with some common observable characteristics (Murenga \& Njuguna, 2020). The study targeted Finance staff, production and engineering staff, procurement officer, and managers of the selected three tea factories in Nandi county. The factories have a total of approximately 1,500 finance, production and engineering, procurement, and managerial staff. A sample of 295 respondents was selected and interviewed (County Government of Nandi, 2020). Semi-structured questionnaires were used. An extra 10\% was selected to take care of non-response. The respondents did not identify themselves by names during the interviews to ensure anonymity and confidentiality.

\section{Table3.1: Target Population}

\begin{tabular}{lll}
\hline Department & Total & \% \\
\hline Finance \& Admin staff & 163 & 10.9 \\
Production \& Engineering & 656 & 43.7 \\
Procurement staff & 515 & 34.3 \\
Manager and supervisor & 166 & 1.1 \\
Total & $\mathbf{1 , 5 0 0}$ & $\mathbf{1 0 0}$ \\
\hline
\end{tabular}

\section{Sampling Technique}

Simple random sampling was used to select respondents from the factories. The researcher identified the total number of staff in production, engineering, finance and procurement departments from which the respondents were then be selected randomly; sampling distribution was used to select a sample for known sigma and proportion. 
$n=$

$1+163\left(0.1^{2}\right)$

$$
=62 \text {. }
$$

\section{Equation 3.2}

\subsubsection{Sampling Frame}

The sampling frame defines a set of elements from which a researcher can select a sample of the target population (Adam, 2020).

\section{Table 3.2: Sample Frame}

\begin{tabular}{lll}
\hline Department & Total & Sample \\
\hline Finance \& Admin staff & 163 & 62 \\
Production \& Engineering & 656 & 87 \\
Procurement staff & 515 & 84 \\
Manager and supervisor & 166 & 62 \\
Total & $\mathbf{1 , 5 0 0}$ & $\mathbf{2 9 5}$ \\
\hline
\end{tabular}

\subsection{Data Collection Instruments}

Semi-structured questionnaires and interview guide were used in collecting data from the respondents. Questionnaires were administered to respondents who are literate (able to read and understand well). Respondents were expected to read and understand the questions and write down the reply in the space meant for the purpose in the questionnaire itself (Kothari, 2016). Further, questionnaires were appropriate in cases where respondents were willing to disclose their identity. The questionnaire consisted of both open-ended and closed-ended questions. The interview guide enabled the generation of more accurate responses free from bias especially targeting the key informants. Interview guides were appropriate for key informants such as, government officials, departmental heads and senior managers.

\section{Pilot study}

A pilot study is research conducted before the intended study. Although they are mini versions of a full-scale study, (Kothari, 2016) points out that pilot studies should be executed as planned for the intended study, but on a smaller scale. Pilot studies help pre-test a particular research instrument such as a questionnaire or interview schedule/guides. One advantage of conducting a pilot study is that it might give warning about where the main research project could fail, where research protocols may not be followed, or whether proposed methods or instruments are inappropriate or too complicated (Cheruiyot, Kibett, \& Ngeno, 2020). A pilot study was conducted in Eldoret Kiptagich tea wholesale in March 2021 to test various indicators of the variables, to test methodological changes to implementation or administration of an instrument, and to test the efficacy of research instruments and protocols. 
International Journal of Supply Chain Management

ISSN 2518-4709 (Online)

Vol.6, Issue 2, No.1, pp 1-11, 2021

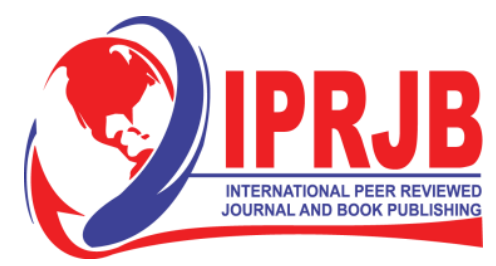

WWW.iprib.org

\section{Data Processing, Analysis, and Presentation}

Data was processed through coding and use of descriptive statistics such as percentages, frequencies and means. Descriptive statistics was used in examining the characteristics of the population. Variable aggregation for different variables was undertaken in facilitation of further statistical analysis. The researcher applied "Collapsing Response" method in analyzing responses from a Likert scale measurement. This was done by adding the "strongly agree" responses with the "agree" responses and also adding the "disagree"e responses with "strongly disagree (Gwavuya, 2011). The purpose of descriptive statistics is to enable the researcher to meaningfully describe the findings.

Inferential statistics was done using correlation analysis, regression analysis and Analysis of Variance (ANOVA). SPSS (Statistical Package for Social Sciences) software aided the analysis. Shapiro-Wilk test was used to test normality and Durbin Watson test to test the autocorrelation of the variables. The correlation analysis performed done between the variables of the study using Pearson correlation coefficient. This tested whether there is any existing interdependency between independent variables. Also, to examine if there exist a significant relationship between the independent variables. Multiple linear regression model was used in testing the significance and influence of the predictor variables on the dependent variable.

\subsection{DATA ANALYSIS, FINDINGS AND DISCUSSIONS}

\subsection{Pilot Test Results}

Cronbach alpha was used by the study to test the reliability of the questionnaire. The study tested the four items in each variable was covered by the study. The Cronbach alpha coefficient of 0.7 and above was the desired level for the reliability of the questionnaire.

\subsubsection{Testing for Normality}

The Shapiro-Wilk test was carried out to check for normality so as to ensure that the residuals in the regression models behaved normal. The results indicated show the p-values of 014602 , 0.84847 and 0.43073 for the variables in the regression model. The $\mathrm{p}$-values are greater than 0.05 implying that the residuals were normally distributed. Therefore, the study failed to reject the null that residuals are normally distributed (at 95\%significance level) and concluded that the residuals behaved normally.

\subsubsection{Test for Autocorrelation}

Autocorrelation occurs when the residuals are not independent from each other (Mark et al., 2015). Little or no autocorrelation in the data is necessary in conducting linear regression analysis. The linear regression model was tested for autocorrelation using Durbin-Watson test. The ranges should be within $1.5<\mathrm{d}<2.5$. From the observed Durbin Watson statistic, there was no serial correlation. This study found a Durbin Watson statistic of 2.106 and being less than 2.5, it indicated absence of serial correlation. 
International Journal of Supply Chain Management

ISSN 2518-4709 (Online)

Vol.6, Issue 2, No.1, pp 1-11, 2021

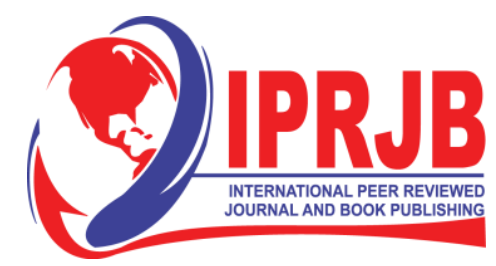

WWW.iprib.org

H01: Ecological design systems have no significant effect on sustainable environmental conservation of tea factories in Nandi County.

The findings on regression analysis reveals that the $t$ value is $=1.970$, similarly, $\mathrm{P}$ value is 0.040 which is less than 0.05 . Table 4.15 is sufficient to show relative importance. In this regard, the rejection of the null hypothesis is justified thus; ecological design significantly affects sustainable environmental conservation of tea factories in Nandi County. This implies that tea factories in Nandi county should be strongly committed to ecological design practices because this can foster higher environmental health and increase their return rate, which would certainly warrant an increase in the environmental performance. These findings are supported by Molina and Claver (2009) who established that ecological design is critical for enhancing the environment conservation as it is the main source of waste. In support of above findings utilizing a sample consisted of 150 companies in electronics industry; Singhal (2013) reported a significant relationship between green design and environmental performance. Beyene (2015) added that green design results in enhanced environmental performance. There is need for the companies to carry out these approaches as noted by Muchiri (2011) that waste management involves source reduction the recycle and re-use waste management programs focuses on management of waste after it has been created. The above shows that tea most of the tea factories most of them have adopted eco-friendly gunny bags for tea delivery. However, the tea factories have not used eco-friendly materials on ventilation; they do not use noise reduction materials, does not package tea in eco-friendly materials after processing, and have inadequate practices on eco-friendly labelling.

\subsection{SUMMARY, CONCLUSIONS AND RECOMMENDATIONS}

\section{Summary}

The first objective of the study sought to determine the effect of the ecological design on sustainable environmental conservation of tea factories in Nandi County. Ecological design practices were found to have positive and significant effect on sustainable environmental conservation of tea factories in Nandi county. The study established that to a large extent, the tea factories have adopted tea delivery gunny bags that are eco-friendly. However, the factories have to a small extent used eco-friendly materials on ventilation, have noise reduction measures, have processed tea packaged in eco-friendly materials, and neither uses eco labelling products and reused packages. In support of above findings utilizing a sample consisting of 150 companies in electronics industry; Singhal (2013) reported a significant relationship between ecological design and environmental performance. Zhang (2015) added that ecological design results in enhanced environmental performance. There is need for the companies to carry out these approaches since as noted by Muchiri (2011), waste management involves source reduction, the recycle and re-use waste management programs focuses on management of waste after it has been created.

\section{Conclusions}

The study concluded that green supply chain management practices have significant effects sustainable environmental conservation. There is positive relationship between Green Supply Chain Management Practices; Ecological design, Reverse logistics, Green production, and Green procurement and sustainable environmental conservation of tea factories in Nandi County. From 
International Journal of Supply Chain Management

ISSN 2518-4709 (Online)

Vol.6, Issue 2, No.1, pp 1-11, 2021

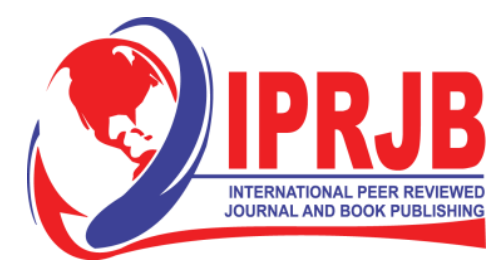

WWW.iprib.org

the regression analysis it was concluded that Green Supply Chain Management practices has a positive effect on sustainable environmental conservation. Organizations that adopt green supply chain management practices experience reduced environmental pollution and reduced cost of environmental management thereby enhancing their sustainable environmental conservation. The effect of green supply chain management practices on sustainable environmental conservation is statistically significant. This result could be attributed to the fact that most tea processing firms in Nandi County started adopting green supply chain strategies in the long ago past and the effects of these practices may have fully been realized. The study therefore recommends that: tea processing firms and other manufacturing firms should consider adopting green supply chain management practices. They should embrace green strategies in their purchasing, manufacturing, distribution, marketing and reverse logistics operations.

\section{Recommendations}

The tea factories should try to adopt and effectively implement green supply chain management practices (Ecological design, Reverse logistic, Green procurement and Green production) to sustainably conserve their environments. Prioritizing this consideration could be a cost today but a benefit in the long run. This is evidenced the tea bonus earning that have greatly improved over the four years. The study also found that other market demand and supply factors have contributed to the growth apart from green supply chain adoption thus further studies on relevancy of other factors contributing to this should be established. Among other practices, the factories should thrive in adopting reverse logistics on already used packaging, this can act as cost reducing method. There is need to also implement eco-designs in the tea factories since most of the factories have not adopted the practice and those who have implemented do not report the expected outcome. There is also need to use of alternative source of energy like the use of briquettes, husks and hydroelectric power which have reduced cost by $75 \%$ for those who have implemented for example Emrok. This study also recommends that trainings programs especially on the approaches of reverse logistics and green procurement practices should be done as majority of the respondents do not understand the concepts and their benefits towards sustainable environmental conservation. The government should also take initiative to ensure that child labour practices are eliminated through strict policies and enforcement of relevant laws. The government and KTDA should also work together to ensure that KTDA officials have the requisite expectations from the government in terms of policy implementation and strengthening both the tea factories and tea farmers.

\section{Suggestions for Further Research}

The two areas for further study are: Studies in other processing firms other than tea processing firms, studies to relate GSCM with other aspects of performance such as economic and social performance and studies to explore other GSCM practices other than green purchasing, green manufacturing, green distribution, green marketing and reverse logistics. The study shows that more can be learnt about GSCM practices by accommodating more views from the players. This study gives room for explanatory studies since some insight has already been obtained. The findings of the study also raise a number of additional research questions which may include similar research being done on other agricultural sector since agriculture is the backbone of the Kenyan economy. 
International Journal of Supply Chain Management

ISSN 2518-4709 (Online)

Vol.6, Issue 2, No.1, pp 1-11, 2021

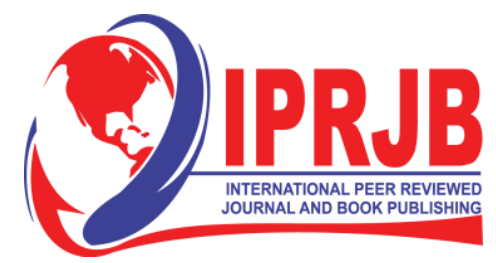

WWW.iprib.org

\section{REFERENCES}

Adam, A. M. (2020). Sample size determination in survey research. Journal of Scientific Research and Reports, 10(3), 90-97.

Adams, J. (2015). Explanatory Research Design. 123-124. Retrieved from https://go4customer.com/glossary/e/what-is-explanatory-approach, 23(4), 145-173.

Amemba, C. S., Nyaboke, P. G., Osoro, A., \& Mburu, N. (2013). Elements of green supply chain management. European Journal of Business and Management, 5(12), 51-61.

Aital, P., \& Vijai, P. (2016). Green 'Supply Chain Management: Resource Allocation Strategies for Sustainable Operations. Strategic Management of Sustainable Manufacturing Operations, 2(1), 1-23.

Asabere, N. Y., Doku, V., Kusi-Sarpong, S., \& Oppong, D. (2014). Adopting electronic business in Ghana: Story of the hospitality industry. International Journal of Computer Applications, 85(4) 423-456.

Azevedo, S. G., Carvalho, H., \& Machado, V. C. (2011). The influence of green practices on supply chain performance: A case study approach. Transportation research part E: logistics and transportation review, 47(6), 850-871.

Barber, N. (2010). Green" wine packaging: targeting environmental consumers. International Journal of Wine Business Research, 5(7), 23-58.

Blakeney, M., \& Mengistie, G. (2012). Kenya: Tea. Extending the Protection of Geographical Indications: Case Studies of Agricultural Products in Africa, 7(3), 213.

Gonzalez-Torre, P. L., Adenso-Diaz, B., \& Artiba, H. (2004). Environmental and reverse logistics policies in European bottling and packaging firms. 80(1), 95-104.

Handfield, R., \& Nichols Jr, E. L. (2002). Supply chain redesign: Transforming supply chains into integrated value systems. 4(3), 71-183.

Henault, S., Podilchak, S. K., Mikki, S. M., \& Antar, Y. M. (2012). A methodology for mutual coupling estimation and compensation in antennas. IEEE Transactions on Antennas and Propagation, 61(3), 1119-1131.

Kagira, E. K., Kimani, S. W., \& Githii, K. S. (2012). Sustainable methods of addressing challenges facing small holder tea sector in Kenya: A supply chain management approach. Journal of management \& Sustainability, 2(75), 217-226.

Molina-Azorin, J. F., Claver-Cortes, E., Pereira-Moliner, J., \& Tari, J. J. (2009). Environmental practices and firm performance: an empirical analysis in the Spanish hotel industry. Journal of Cleaner production, 17(5), 516-524.

Mugenda, N. G., Momanyi, G., \& Naibei, K. I. (2012). Implications of risk management practices on financial performance of sugar manufacturing firms in Kenya. AFRREV IJAH: An International Journal of Arts and Humanities, 1(1), 14-29.

Mugo, B. N. (2017). Effect of Green Supply Chain Management Practices on Performance of Tea Factories in Nandi County Kenya. 2(1), 23-37. 
International Journal of Supply Chain Management

ISSN 2518-4709 (Online)

Vol.6, Issue 2, No.1, pp 1-11, 2021

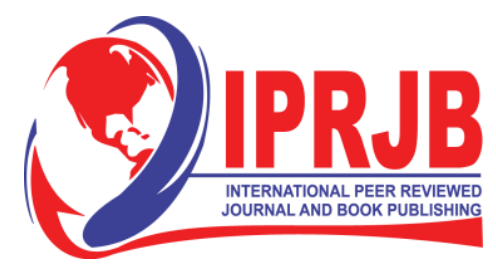

WWW.iprib.org

Mukiri, P. M. (2007). Green supply chain management practices by manufacturing firms in Kenya. 1(1), 33-53.

Mule, R. K., Ingari, B. A., Obura, J. M., Ondoro, C. O., \& Thairu, S. N. (n.d.). (2012). Procurement Best Practices, A Potential Solution to Kenya's Supermarket Performance Problem. 6(1), 34-36.

Muma, B. O., Nyaoga, R. B., Matwere, R. B., \& Nyambega, E. (2014). Green supply chain management and environmental performance among tea processing firms in Kericho County-Kenya. International Journal of Economics, Finance and Management Sciences, 2(5), 270-276.

Murenga, Y. A., \& Njuguna, R. (2020). Total quality management practices and service delivery of small and medium enterprises: Case of Horizons Offices Limited in Kenya. 3(8), 207 226.

Mzembe, A. N., Lindgreen, A., Maon, F., \& Vanhamme, J. (2016). Investigating the drivers of corporate social responsibility in the global tea supply chain: A case study of Eastern Produce Limited in Malawi. Corporate Social Responsibility and Environmental Management, 23(3), 165-178.

Naim, M. M., Potter, A. T., Mason, R. J., \& Bateman, N. (2006). The role of transport flexibility in logistics provision. The International Journal of Logistics Management. 3(11), 56-87.

Nandi, C. G. (2020). Blog post. Retrieved from https://nandicounty.go.ke/nandi-county-teafarmers-rural-saccos-consultative-

meeting/\#: :text=Some\%20of\%20the\%20challenges\%20highlighted,to\%20farmers\%20d isadvantage\%20among\%20others.

Priyadarshini, M., \& Bolstad, M. (2018). Mining legacy across a wetland landscape: high mercury in Upper Peninsula (Michigan) rivers, lakes, and fish. Environmental Science: Processes \& Impacts, 20(4), 708-733.

Rao, P., \& Holt, D. (2005). Do green supply chains lead to competitiveness and economic performance?. International journal of operations \& production management.10(5), 65178.

Yu, W., \& Ramanathan, R. (2015). An empirical examination of stakeholder pressures, green operations practices and environmental performance. International Journal of Production Research, 53(21), 6390-6407.

Zhang, X., Pérez-Rodríguez, P., Semagn, K., Beyene, Y., Babu, R., López-Cruz, M. A., ... \& Crossa, J. (2015). Genomic prediction in biparental tropical maize populations in waterstressed and well-watered environments using low-density and GBS SNPs. Heredity, 114(3), 291-299.

Zhu, Q., Sarkis, J., \& Geng, Y. (2005). Green supply chain management in China: pressures, practices and performance. International journal of operations \& production management, 6(2), 66-73. 